\title{
Effect of heparin on the expression of calmodulin-binding proteins in bull spermatozoa*
}

\author{
P. Leclerc, J. Langlais, R. D. Lambert, M. A. Sirard and J. G. Chafouleas $\dagger$ \\ Ontogénie et Reproduction* and $† M R C$ Group in Molecular Endocrinology, Centre de recherche du \\ CHUL, 2705 Laurier Boulevard, Sante-Foy, Québec, Canada GIV $4 G 2$
}

\begin{abstract}
Summary. $\mathrm{A}^{125}$ I-labelled calmodulin gel overlay procedure in the presence and the absence of $\mathrm{Ca}^{2+}$ was used to evaluate bull spermatozoa calmodulin-binding proteins. Frozen spermatozoa were thawed, washed and incubated for $6 \mathrm{~h}$ before being processed for SDS polyacrylamide gel electrophoresis and the ${ }^{125}$ I-labelled calmodulin gel overlay procedure. In non-incubated spermatozoa, up to 14 binding proteins were detected. Some exhibited greater calmodulin binding in the presence of $\mathrm{Ca}^{2+}$ while others exhibited greater binding when $\mathrm{Ca}^{2+}$ was absent. When heparin $(2 \mu \mathrm{g} / \mathrm{ml})$ was present in the incubation medium, a decrease in the calmodulin binding to the proteins of $M_{\mathrm{r}} 28000$ and 30000 was detected in the presence of $\mathrm{Ca}^{2+}$ and EGTA. This effect of heparin was time- and dose-dependent and was increased by the presence of the acrosin inhibitor benzamidine. Sperm capacitation could thus be related to a decrease in the binding of calmodulin to these proteins.
\end{abstract}

Keywords: bull; spermatozoa; calmodulin; calmodulin-binding proteins; heparin; capacitation

\section{Introduction}

Successful in-vitro fertilization has been achieved in cattle following capacitation treatment of spermatozoa with a hyperosmotic medium (Brackett et al., 1982; Sirard \& Lambert, 1985; Sirard et al., 1985; Lambert et al., 1986) or with the glycosaminoglycan heparin (Parrish et al., 1985, 1986a,b, 1988). The molecular mechanisms are still not elucidated, but $\mathrm{Ca}^{2+}$ is recognized as one of the most important factors involved in the process of capacitation (Fraser, 1982, 1987). The exact role of $\mathrm{Ca}^{2+}$ in capacitation is not yet well defined, but it has been demonstrated to stimulate the activities of acrosin (Siegel et al., 1986) and phospholipase $\mathrm{A}_{2}$ (Thakkar et al., 1983, 1984).

Calmodulin is an ubiquitous $\mathrm{Ca}^{2+}$ binding protein which regulates a large number of enzymes (for review, see Cheung, 1980; Means et al., 1982). Immunofluorescence techniques have demonstrated that calmodulin is present in the head region of mammalian spermatozoa, preferentially around the acrosome (Jones et al., 1980), and closely localized to the region containing phospholipase $\mathrm{A}_{2}$ (Weinman et al., 1986), an enzyme which has been reported to be modulated by calmodulin (Moskowitz et al., 1983). Moreover, several calmodulin-binding proteins have been identified in the acrosomal region of hamster (Moore \& Dedman, 1984) and cattle (Olson et al., 1985) spermatozoa. It therefore seems possible that calmodulin is involved directly or through its $\mathrm{Ca}^{2+}$-binding properties in the capacitation/acrosome reaction processes. As calmodulin antagonists have been reported to induce the acrosome reaction in guinea-pig spermatozoa (Nagae \& Srivastava, 1986) and outer acrosomal membrane vesiculation in boar spermatozoa (Berruti et al., 1985), the question to be asked is how is calmodulin implicated in these processes?

*Reprint requests to Dr R. D. Lambert. 
Since calmodulin mediates its regulation by associating with calmodulin-binding proteins, the purpose of the present study was to evaluate the effects of various treatments which induce in-vitro capacitation on the expression of the calmodulin-binding proteins in bovine spermatozoa.

\section{Materials and Methods}

Culture media. Three media that contained $2 \cdot 1 \mathrm{mM}-\mathrm{CaCl}_{2}$ were used for sperm treatments: (1) $\mathrm{DM}$ medium as described by Brackett \& Oliphant (1975) containing $3 \mathrm{mg}$ fatty acid-free bovine serum albumin (BSA)/ml (Sigma, St Louis, MO, USA) and antibiotics (50 i.u. penicillin $\mathrm{G} / \mathrm{ml}$ and $50 \mu \mathrm{g}$ streptomycin $/ \mathrm{ml}$ : Gibco, Burlington, Ontario, Canada); (2) Sp-TALP medium (Parrish et al., 1988) supplemented with $6 \mathrm{mg} \mathrm{BSA} / \mathrm{ml}$ and $100 \mathrm{i}$.u. antibiotics/ml but containing no gentamycin; and (3), Sp-TALP medium containing various concentrations of heparin (178 i.u./mg (Sigma)). In one set of experiments, benzamidine (Sigma) was added to the treatment medium containing heparin at a final concentration of $50 \mathrm{~mm}$.

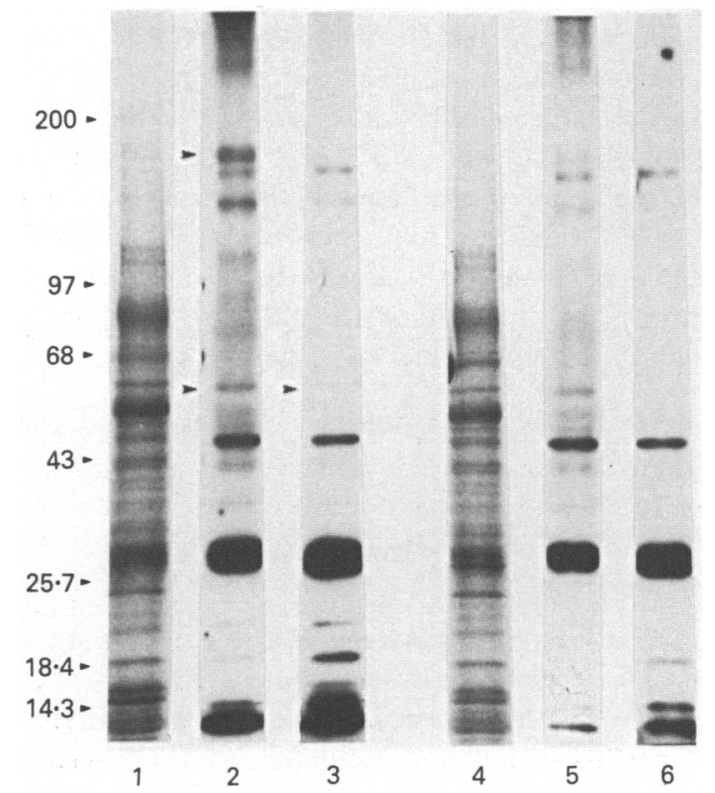

Fig. 1. Calmodulin-binding proteins in spermatozoa from Bulls 1 (Lanes 1, 2 and 3) and 2 (Lanes 4, 5 and 6). Sperm cells were washed as specified in the 'Materials and Methods' without incubation. Proteins were extracted from $10 \times 10^{6}$ bull spermatozoa, electrophoresed and subjected to the ${ }^{125} \mathrm{I}$-labelled calmodulin overlay procedure as described in the 'Materials and Methods'. Lanes 1 and 4 are Coomassie blue-stained proteins extracted from spermatozoa; Lanes 2 and 5 are autoradiograms of calmodulin-binding proteins in the presence of $1 \mathrm{mM}$ $\mathrm{CaCl}_{2}$ and Lanes 3 and 6 are autoradiograms of calmodulin binding proteins in the presence of 1 mM-EGTA. Molecular weight markers $\left(M_{\mathrm{r}} \times 10^{-3}\right)$ are indicated at the left.

Sperm preparation. Frozen straws of spermatozoa from 5 different bulls were generously donated by the Centre d'Insémination Artificielle du Québec (C.I.A.Q. Inc., St-Hyacinthe, Québec, Canada). The straws were thawed in a water bath $\left(37^{\circ} \mathrm{C}\right)$ for $10 \mathrm{sec}$ and the spermatozoa were washed twice $\left(5 \mathrm{~min}, 250 \mathrm{~g}, 37^{\circ} \mathrm{C}\right)$ in normal saline $(0.9 \%$ $\mathrm{NaCl}, \mathrm{w} / \mathrm{v}, \mathrm{pH} 7.4)$ and then routinely resuspended at $10 \times 10^{6} \mathrm{cells} / \mathrm{ml}$ in a final volume of $5 \mathrm{ml}$ of the different treatment media. When experiments were performed to characterize the effect of heparin, spermatozoa were washed in Sp-TALP medium instead of saline. After a 6-h incubation $\left(37^{\circ} \mathrm{C}, 5 \% \mathrm{CO}_{2}\right)$, cells were centrifuged and washed once in saline or Sp-TALP medium without BSA. Proteins were then solubilized from the sperm pellet according to the method of Laemmli $(1970)$ and sonicated twice $(15 \mathrm{sec})$ to facilitate the protein extraction.

Electrophoresis and ${ }^{125}$ I-labelled calmodulin overlays. Proteins extracted from 7-10 $\times 10^{6}$ spermatozoa were electrophoresed in triplicate on 5-15\% linear gradient SDS-polyacrylamide gels (Laemmli, 1970). One gel was stained 


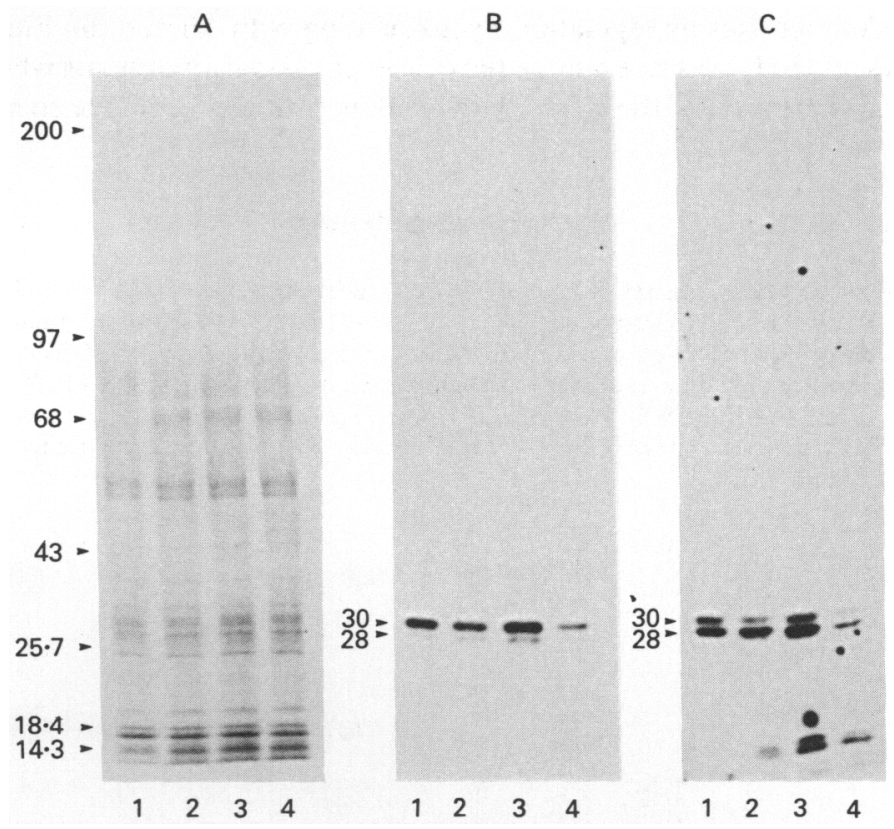

Fig. 2. Effect of capacitation treatment on the patterns of bull calmodulin-binding proteins in bull spermatozoa. Spermatozoa were subjected to different in-vitro capacitation treatments as described in the 'Materials and Methods' and processed as in Fig. 1. The binding proteins of $M_{\text {r }}$ 28000 and 30000 are indicated. A, Coomassie blue-stained proteins extracted from $10 \times 10^{6}$ bull spermatozoa; $B$, autoradiograms of binding proteins obtained in the presence of $1 \mathrm{~mm}$ $\mathrm{CaCl}_{2} ; \mathrm{C}$, autoradiograms of binding proteins obtained in the presence of 1 mM-EGTA. Lane 1 , proteins extracted from spermatozoa before a 6-h incubation; Lane 2, proteins extracted from spermatozoa incubated for $6 \mathrm{~h}$ in DM medium; Lane 3, proteins extracted from spermatozoa incubated for $6 \mathrm{~h}$ in Sp-TALP medium; Lane 4, proteins extracted from spermatozoa incubated for $6 \mathrm{~h}$ in Sp-TALP medium containing $2 \mu \mathrm{g}$ heparin $/ \mathrm{ml}$. Molecular weight markers $\left(M_{\mathrm{r}} \times 10^{-3}\right)$ are indicated.

with Coomassie blue while the other two were processed for ${ }^{125}$ I-labelled calmodulin overlay, one in the presence of $1 \mathrm{mM}-\mathrm{CaCl}_{2}$ and the other in the presence of $1 \mathrm{~mm}$-ethyleneglycol bis-( $\beta$-aminoethyl ether)- $N, N, N^{\prime}, N^{\prime}$-tetra-acetic acid (EGTA). This technique was performed as described by Nelson et al. (1983). Since the primary sequence of calmodulin is highly conserved among species (Means $e t$ al., 1982), these studies utilized calmodulin prepared from rat testis (Dedman et al., 1977). ${ }^{125} \mathrm{I}$-labelled calmodulin which retained full biological and immunological potency was prepared as previously described (Chafouleas et al., 1979). At the end of the overlay procedure, gels were dried and subjected to autoradiography using Kodak XAR-5 film.

\section{Results}

\section{Calmodulin-binding proteins}

While minor differences were observed between the calmodulin-binding proteins of the 5 bulls, the major pattern obtained after treatment was consistent for all. Therefore, except for Fig. 1, results from only one bull are presented in this study.

As shown in Fig. 1, up to 14 calmodulin-binding proteins were detected. One of these binding proteins $\left(M_{\mathrm{r}} 170000\right)$ required $\mathrm{Ca}^{2+}$ for binding to calmodulin while another $\left(M_{\mathrm{r}} 17000\right)$ bound only in the absence of $\mathrm{Ca}^{2+}$. Other binding proteins, e.g. that of $M_{\mathrm{r}} 62000$, exhibited greater binding when $\mathrm{Ca}^{2+}$ was present for the overlay, while others, such as those between $M_{\mathrm{r}} 14000$ and 
A

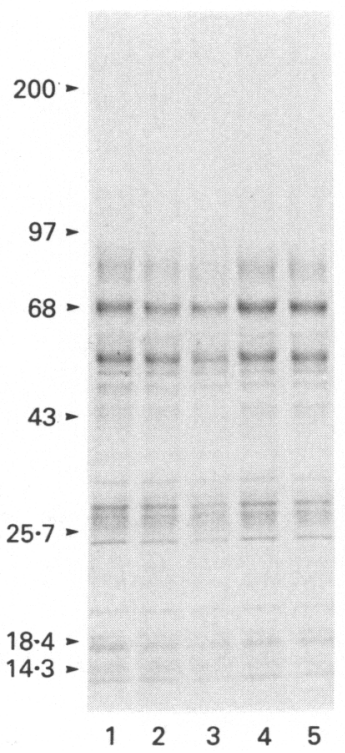

B

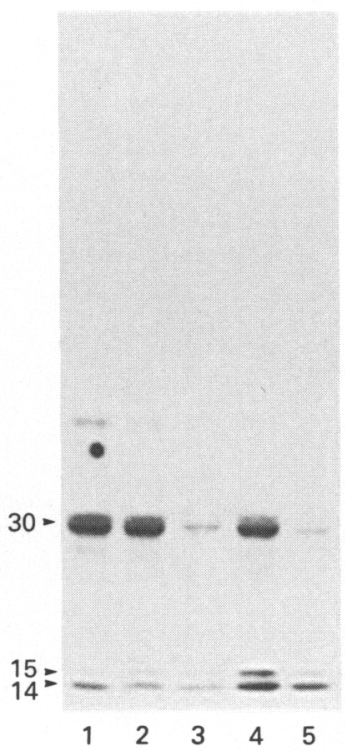

C

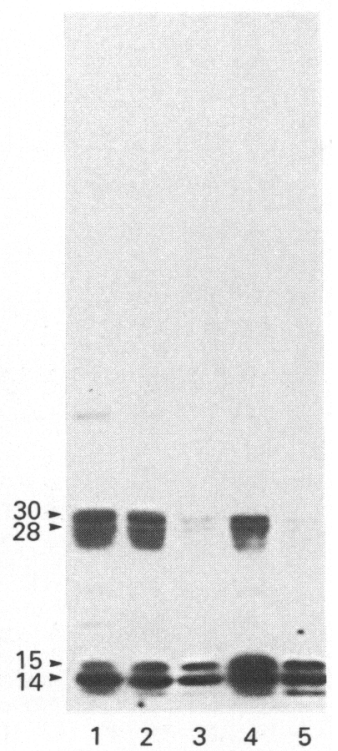

Fig. 3. Effect of benzamidine on the heparin-altered pattern of calmodulin-binding proteins of bull spermatozoa. Spermatozoa were treated with heparin in the presence of benzamidine as described in the 'Materials and Methods' and processed as in Fig. 1. The proteins of $M_{\mathrm{r}} 28000$ and 30000 are indicated. A, Coomassie blue-stained proteins extracted from $10 \times 10^{6}$ spermatozoa; $\mathrm{B}$, autoradiogram of binding protein in the presence of $1 \mathrm{mM}-\mathrm{CaCl}_{2} ; \mathrm{C}$, autoradiogram of binding protein in the presence of 1 mM-EGTA. Lane 1, proteins extracted before the 6-h incubation; Lanes 2, 3, 4 and 5, proteins extracted after sperm incubation for $6 \mathrm{~h}$ in Sp-TALP medium alone or containing $2 \mu \mathrm{g}$ heparin $/ \mathrm{ml}, 50 \mathrm{~mm}$-benzamidine or $50 \mathrm{~mm}$-benzamidine plus $2 \mu \mathrm{g}$ heparin $/ \mathrm{ml}$ respectively. Molecular weight markers $\left(M_{\mathrm{r}} \times 10^{-3}\right)$ are indicated.

30000 , exhibited greater binding to calmodulin in the presence of 1 mM-EGTA. Figure 1 demonstrates the similarity in the binding protein pattern for the 2 bulls.

\section{Capacitation treatments}

When spermatozoa were incubated in DM or Sp-TALP media, a 6-h incubation had no effect on the pattern of calmodulin-binding proteins in the presence of $1 \mathrm{mM}^{-\mathrm{Ca}^{2+}}$ or $1 \mathrm{mM}-\mathrm{EGTA}$ (Fig. 2). The addition of heparin to the Sp-TALP medium resulted in a decrease in calmodulin binding to the proteins of $M_{\mathrm{r}} 28000$ and 30000 in the presence or absence of $\mathrm{Ca}^{2+}$. The Coomassie blue gel revealed no apparent difference for the sperm proteins in these molecular weight regions. The same effects of heparin were obtained when $\mathrm{Ca}^{2+}$ was omitted in the Sp-TALP medium. Preliminary experiments using in-vitro matured oocytes resulted in rates of $5 \%$ and $51 \%$ in-vitro fertilization for spermatozoa incubated respectively in Sp-TALP and Sp-TALP containing $2 \mu \mathrm{g}$ heparin $/ \mathrm{ml}$.

\section{Effect of benzamidine}

When benzamidine, a protease inhibitor, was added to spermatozoa incubated for $6 \mathrm{~h}$ in the presence or absence of heparin, benzamidine alone did not modify the calmodulin binding to the proteins of $M_{\mathrm{r}} 28000$ and 30000 but a greater binding to proteins of $M_{\mathrm{r}} 14000$ and 15000 was observed when the overlay was performed in the presence of $1 \mathrm{~mm}-\mathrm{Ca}^{2+}$ or $1 \mathrm{~mm}$-EGTA (Fig. 3). 


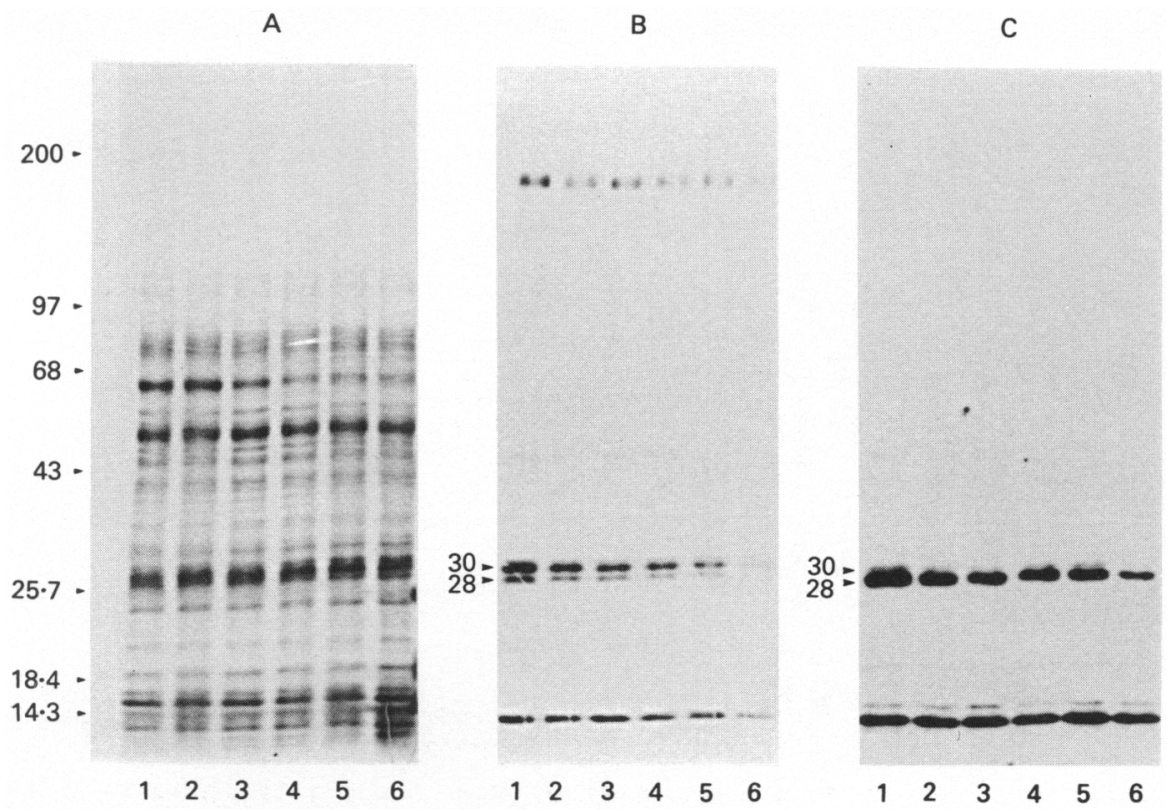

Fig. 4. Time-dependent effect of heparin $(2 \mu \mathrm{g} / \mathrm{ml})$ on the calmodulin-binding proteins of $M_{\mathrm{r}} 28000$ and 30000 . Spermatozoa were incubated with $2 \mu \mathrm{g}$ heparin $/ \mathrm{ml}$ for the designated time as described in the 'Materials and Methods' and processed as in Fig. 1. The binding proteins of $M_{\mathrm{r}} 28000$ and 30000 are indicated. A, Coomassie blue-stained proteins; B, autoradiograms of binding proteins in the presence of $1 \mathrm{mM}-\mathrm{CaCl}_{2} ; \mathrm{C}$, autoradiogram of binding proteins in the presence of $1 \mathrm{~mm}$-EGTA. Lanes $1-6$ are proteins extracted from spermatozoa incubated for $0,1,2,3,4$ and $6 \mathrm{~h}$ respectively in the presence of $2 \mu \mathrm{g}$ heparin/ml heparin. Molecular weight markers $\left(M_{\mathrm{r}} \times 10^{-3}\right)$ are indicated.

However, addition of benzamidine to the heparin-containing medium slightly increased the heparin effect by causing a reduction in the calmodulin binding to the proteins of $M_{\mathrm{r}} 28000$ and 30000 as observed on the $\mathrm{Ca}^{2+}$ and EGTA overlays. Although this variation was weak, it was reproducible.

\section{Effect of heparin}

As shown in Fig. 4, there was a time-dependent decrease in calmodulin binding during the 6-h incubation period. In the presence of $1 \mathrm{~mm}-\mathrm{Ca}^{2+}$, the decrease was regular until only a weak signal was observed by $6 \mathrm{~h}$. No such gradual decrease was observed in the presence of EGTA even though the calmodulin binding was much lower at $6 \mathrm{~h}$. In fact, a two-step decrease was observed. When spermatozoa were incubated for $6 \mathrm{~h}$ with increasing concentrations of heparin, there was a continuous decrease in calmodulin binding (Fig. 5). While a decrease in calmodulin binding to the protein of $M_{\mathrm{r}} 14000$ was observed after a 6-h incubation with heparin (Fig. 4), there was no effect of the heparin concentration on this change in calmodulin binding (Fig. 5).

\section{Discussion}

Calmodulin has been demonstrated to regulate a large number of enzymes through the specific association with proteins known as calmodulin-binding proteins (Cheung, 1980; Means et al., 1982). The present study demonstrates that bovine spermatozoa contain many such proteins, most of which bind calmodulin in the presence or absence of $\mathrm{Ca}^{2+}$. Incubation of spermatozoa with heparin modifies the pattern of calmodulin-binding proteins observed. 
A

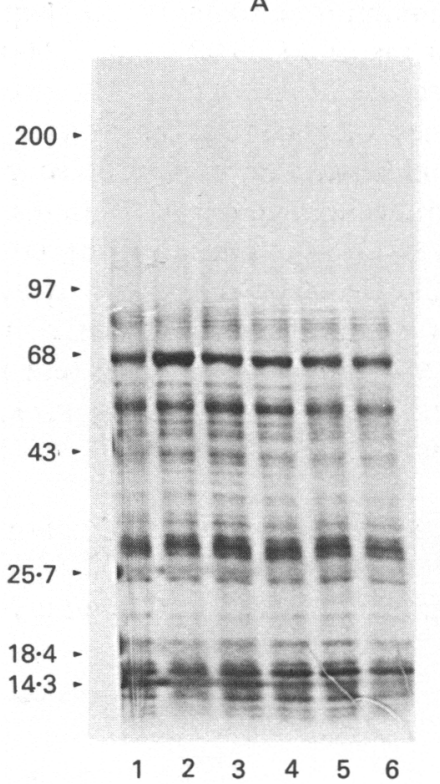

B

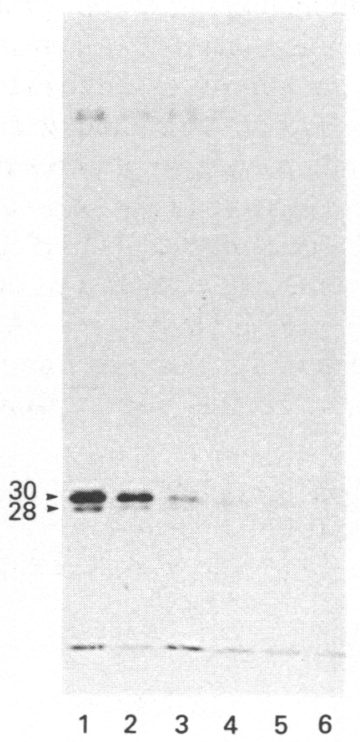

C

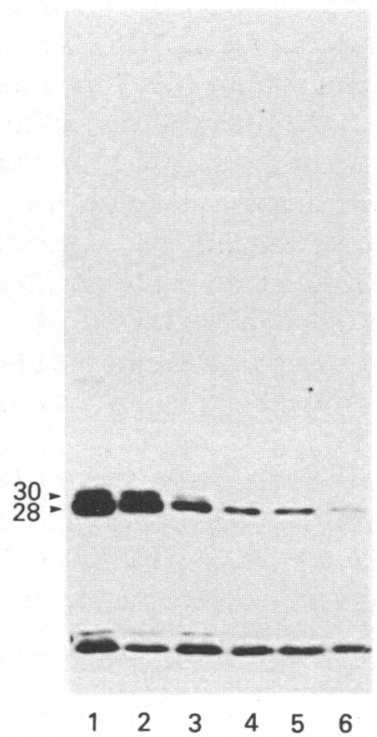

Fig. 5. Dose-dependent effect of heparin on the calmodulin-binding proteins of $M_{\mathrm{r}} 28000$ and 30000 after a 6-h incubation. Spermatozoa were incubated in the presence of increasing doses of heparin from 0 to $10 \mu \mathrm{g} / \mathrm{ml}$ and processed as in Fig. 1. The proteins of $M_{\mathrm{r}} 28000$ and 30000 are indicated. A, Coomassie blue-stained proteins; B, autoradiograms of binding proteins in the presence of $1 \mathrm{mM}-\mathrm{CaCl}_{2} ; \mathrm{C}$, autoradiograms of binding proteins in the presence of $1 \mathrm{~mm}$ EGTA. Lane 1, proteins extracted from spermatozoa before the 6-h incubation. Lanes 2-6 are proteins extracted from spermatozoa after a 6 -h incubation in the presence of $0,0 \cdot 5,1,2$ and $10 \mu \mathrm{g}$ heparin $/ \mathrm{ml}$, respectively. Molecular weight markers $\left(M_{\mathrm{r}} \times 10^{-3}\right)$ are indicated.

In fact, heparin treatment causes a decrease in the binding of calmodulin for at least two binding proteins. This effect depends on the length of the time of incubation as well as the concentration of heparin in the incubation medium. While the localization and role of the $M_{\mathrm{r}} 28000$ and 30000 calmodulin-binding proteins are not described in the present study, the changes in the binding of calmodulin to these two proteins caused by heparin may be functionally linked to sperm capacitation since the in-vitro fertilization rate increases considerably as the heparin concentration increases in the sperm-oocyte incubation medium (Parrish et al., 1988). Moreover, oocyte fertilization occurred only when the sperm cells were incubated for at least $4 \mathrm{~h}$ (Parrish et al., 1988), as was the observed decrease in the calmodulin binding to the $M_{\mathrm{r}} 28000$ protein when the overlay procedure is performed in the absence of $\mathrm{Ca}^{2+}$ (Fig. 4, Panel C).

Heparin is now well recognized as a capacitating agent instead of an acrosome reactioninducing agent (Parrish et al., 1986a, 1988). The mechanisms by which heparin facilitates sperm capacitation and stimulates $\mathrm{Ca}^{2+}$ uptake (Handrow et al., 1986) have still to be elucidated. Since there were no differences in the present study in the pattern of calmodulin-binding proteins or the total electrophoretic protein pattern between spermatozoa in which heparin treatment was performed in the presence or absence of $2 \cdot 1 \mathrm{mM}_{-} \mathrm{Ca}^{2+}$, this would suggest that, during sperm capacitation, $\mathrm{Ca}^{2+}$ uptake could follow the decreased calmodulin binding to the proteins of $M_{\mathrm{r}} 28000$ and 30000 .

Several mechanisms could be implicated in the decreased binding of calmodulin to the binding proteins. Such a decrease could be due to changes in the amounts of the binding proteins. This can be accomplished by a variety of mechanisms, one of which is proteolysis. Heparin and $\mathrm{Ca}^{2+}$, separately or together, have been shown to stimulate the activity of acrosin (Siegel et al., 1986). 
However, co-incubation of spermatozoa with the protease inhibitor benzamidine and heparin did not reverse the decreased calmodulin binding to the proteins of $M_{\mathrm{r}} 28000$ and 30000 caused by heparin alone. In fact, benzamidine seemed to increase the heparin effect. The decrease in calmodulin binding therefore does not appear to be due to the single action of the protease acrosin. However, the cause of the additive effect of benzamidine and heparin must be resolved in further studies. Changes in calmodulin binding can also be effected through modifications to the binding proteins. Phosphorylation of myosin light chain kinase (a calmodulin-binding protein) results in an inhibition of binding by calmodulin (Nishikawa et al., 1985). This may be a promising avenue to explore since Olsen et al. (1985) have shown that proteins of the outer acrosomal membrane in the $M_{\mathrm{r}} 12000-34000$ region can be phosphorylated in a cAMP- and $\mathrm{Ca}^{2+}$-independent manner. Future studies will be directed at determining the mechanisms by which the decrease in expression of calmodulin binding proteins occurs during sperm capacitation.

We thank C.I.A.Q. Inc. for the gift of spermatozoa; F. Dô for calmodulin iodination; and J. Poulin and E. Leclerc for typing of the manuscript.

The work was supported by the Canadian Medical Research Council (J.G.C.) and le Fonds de la Recherche en Santé du Québec (P.L. and J.L.).

\section{References}

Berruti, G., Anelli, G. \& Camatini, M. (1985) The effects of anti-calmodulin drugs on the ultrastructure of boar spermatozoa Eur. J. Cell Biol. 39, 147-152.

Brackett, B.G. \& Oliphant, G. (1975) Capacitation of rabbit spermatozoa in vitro. Biol. Reprod. 12, 260274.

Brackett, B.G., Bousquet, D., Boice, M.L., Donawick, W.J., Evans, J.F. \& Dressel, M.A. (1982) Normal development following in vitro fertilization in the cow. Biol. Reprod. 27, 147-158.

Chafouleas, J.G., Dedman, J.R., Munjaal, R.P. \& Means, A.R. (1979) Calmodulin, development and application of a sensitive radioimmunoassay. J. biol. Chem. 254, 10262-10267.

Cheung, W.Y. (1980) Calmodulin plays a pivotal role in cellular regulation. Science, N.Y. 207, 19-27.

Dedman, J.R., Potter, J.D., Jackson, R.L., Johnson, J.D. \& Means, A.R. (1977) Physicochemical properties of rat testis $\mathrm{Ca}^{2+}$-dependent regulator protein of cyclic nucleotide phosphodiesterase. Relationship of $\mathrm{Ca}^{2+}$-binding, conformational changes and phosphodiesterase activity. J. biol. Chem. 252, $8415-8422$.

Fraser, L.R. (1982) $\mathrm{Ca}^{2+}$ is required for mouse sperm capacitation and fertilization in vitro. $J$. Androl. 3, 412-419.

Fraser, L.R. (1987) Minimum and maximum extracellular $\mathrm{Ca}^{2+}$ requirements during mouse sperm capacitation and fertilization in vitro. J. Reprod. Fert. 81, 77-89.

Handrow, R.R., Parrish, J.J. \& First, N.L. (1986) Heparin stimulates calcium uptake by bovine sperm in vitro. J. Androl. 7, 23, abstr.

Jones, H.P., Lenz, R.W., Palevitz, B.A. \& Cormier, M.J. (1980) Calmodulin localization in mammalian spermatozoa. Proc. natn. Acad. Sci. USA 77, 2772-2776.

Laemmli, W.K. (1970) Cleavage of structural proteins during the assembly of the head bacteriophage T4. Nature, Lond 227, 680 685.
Lambert, R.D., Sirard, M.A., Bernard, C., Béland, R., Rioux, J.E., Leclerc, P., Ménard, D.P. \& Bedoya, M. (1986) In vitro fertilization of bovine oocytes matured in vivo and collected at laparoscopy. Theriogenology 25, 117-133.

Means, A.R., Tash, J.S. \& Chafouleas, J.G. (1982) Physiological implications of the presence, distribution and regulation of calmodulin in eukaryotic cells. Physiol. Rev. 62, 1-38.

Moore, P.B. \& Dedman, J.R. (1984) Calmodulin, a calmodulin acceptor protein, and calcimedins: unique antibody localizations in hamster spermatozoa. $J$. Cell. Biochem. 25, 99-107.

Moskowitz, N., Shapiro, L., Schook, W. \& Puszkin, S. (1983) Phospholipase A2 modulation by calmodulin, prostaglandins and cyclic nucleotides. Biochem. Biophys. Res. Commun. 115, 94-99.

Nagae, T. \& Srivastava, P.N. (1986) Induction of the acrosome reaction in guinea pig spermatozoa by calmodulin antagonist W-7. Gamete Res. 14, 197208.

Nelson, T.Y., Oberwetter, J.M., Chafouleas, J.G. \& Boyd, A.E., III (1983) Calmodulin-binding proteins in a cloned rat insulinoma cell line. Diabetes 32, 1126-1133.

Nishikawa, M., Shirakawa, S. \& Adelstein, R.S. (1985) Phosphorylation of smooth muscle myosin light chain kinase by protein kinase $\mathrm{C}$. Comparative study of the phosphorylated sites. J. biol. Chem. 260, 89788983.

Olson, G.E., Winfrey, V.P., Garbers, D.L. \& Noland, T.D. (1985) Isolation and characterization of a macromolecular complex associated with the outer acrosomal membrane of bovine spermatozoa. Biol. Reprod. 33, 761-779.

Parrish, J.J., Susko-Parrish, J.L. \& First, N.L. (1985) Effect of heparin and chondroitin sulfate on the acrosome reaction and fertility of bovine sperm in vitro. Theriogenology 24, 537-549. 
Parrish, J.J., Susko-Parrish, J.L. \& First, N.L. (1986a) Capacitation of bovine sperm by oviduct fluid or heparin is inhibited by glucose. J. Androl. 7, 22, Abstr.

Parrish, J.J., Susko-Parrish, J.L., Leibfried-Rutledge, M.L., Critser, E.S., Eyestone, W.H. \& First, N.L. (1986b) Bovine in vitro fertilization with frozenthawed semen. Theriogenology 25, 591-600.

Parrish, J.J., Susko-Parrish, J., Winer, M.A. \& First, N.L. (1988) Capacitation of bovine sperm by heparin. Biol. Reprod. 38, 1171-1180.

Siegel, M.A., Bechtold, D.S., Kopta, C.I. \& Polakoski, K.L. (1986) Quantification and partial characterization of the hamster sperm proacrosin-acrosin system. Biol. Reprod. 35, $485-491$.

Sirard, M.A. \& Lambert, R.D. (1985) In vitro fertilization of bovine follicular oocytes obtained by laparoscopy. Biol. Reprod. 33, 487-494.
Sirard, M.A., Lambert, R.D., Ménard, D.P. \& Bedoya, M. (1985) Pregnancies after in vitro fertilization of cow follicular oocytes, their incubation in rabbit oviduct and their transfer to the cow uterus. J. Reprod. Fert. 75, 551-556.

Thakkar, J.K., East, J., Seyler, D. \& Franson, R.C. (1983) Surface-active phospholipase A2 in mouse spermatozoa. Biochim. Biophys. Acta 754, 44-50.

Thakkar, J.K., East, J. \& Franson, R.C. (1984) Modulation of phospholipase A2 activity associated with human sperm membranes by divalent cations and calcium antagonists. Biol. Reprod. 30, 679-686.

Weinman, S., Ores-Carton, C., Rainteau, D. \& Puszkin, S. (1986) Immunoelectron microscopic localization of calmodulin and phospholipase A2 in spermatozoa. I. J. Histochem. Cytochem. 34, 1171-1179.

Received 25 July 1988 